\title{
Debt Stabilization and Debt Mutualization in a Monetary Union with Endogenous Risk Premia
}

\author{
Jacob Engwerda \\ Bas van Aarle \\ Arie Weeren
}

\author{
CESIFO WORKING PAPER NO. 5564 \\ CATEgory 6: FisCAl Policy, Macroeconomics ANd GrowTH \\ OCTOBER 2015
}

An electronic version of the paper may be downloaded

- from the SSRN website:

www.SSRN.com

- from the RePEc website:

- from the CESifo website:

www.RePEc.org

www.CESifo-group.org/wp 


\title{
Debt Stabilization and Debt Mutualization in a Monetary Union with Endogenous Risk Premia
}

\begin{abstract}
In this paper we analyse debt stabilization in a monetary union that features endogenous risk premia. In particular, we analyse debt stabilization in two diametrically opposed regimes. In the first regime, the "national fiscal discipline regime", financial markets impose sovereign risk premia based on each country's government debt level. In the second regime, the "eurobonds Regime”, financial markets impose a risk premium based on the average debt level in the monetary union. We compare outcomes in both regimes using simulations of a number of relevant scenarios.
\end{abstract}

JEL-Code: C320, H630, H680, H810.

Keywords: Eurobonds, sovereign debt sustainability, sovereign debt crisis.

\author{
Jacob Engwerda \\ Tilburg University / The Netherlands \\ engwerda@uvt.nl
}

\author{
Bas van Aarle* \\ VIVES KU Leuven \\ Janseniusstraat 1 \\ Belgium - 3000 Leuven \\ bas.vanaarle@econ.kuleuven.be
}

Arie Weeren

University of Antwerp / Belgium

arie.weeren@uantwerpen.be

*corresponding author

October 1, 2015

We thank participants of a lunch seminar at the University of Bonn for their insightful questions. 


\section{Introduction}

During the recent years, Europe in general and the Eurozone in particular faced a ravaging financial-, sovereign debt-, and economic growth crisis. Understanding the causes of this crisis and addressing the consequences has been top priority of politicians and economists even if there are no simple explanations and solutions. The impact of the crisis was also not evenly spread as Member States have differed significantly in initial conditions, the dynamics of their fiscal balance and other measures, in their growth dynamics and in risk premia imposed on sovereign debt of countries. Clearly, a combination of high fiscal deficits, low growth and high risk premia on sovereign debt generates a high pace of government debt accumulation. In addition, there is large uncertainty about the future adjustment of these variables and if current debt levels are sustainable (or not). Several Member States risk to enter a process of unsustainable government debt accumulation if no adjustment measures are taken.

Clearly countries not participating in a monetary union like the Eurozone would also risk similar debt dynamics and uncertainty when facing the same conditions. However, it has often been emphasized that countries in a monetary union like the Eurozone face additional constraints in reacting to a sovereign debt crisis, compared to non Member States. First of all, countries in a monetary union no longer have national monetary policy instruments at their disposal. Also they face restrictions on the use on fiscal policy in the form of deficit and debt restrictions from the Stability and Growth Pact. Moreover, the Eurozone entered the debt crisis without any crisis resolution mechanism or any form of debt mutualisation or any other form of fiscal federalism reflecting the underlying principles of subsidiarity and the "no-bailout clause", art 125 of the EU Treaty ${ }^{1}$. Finally, countries in a monetary union could be facing contagion problems in sovereign debt markets, as financial markets could speculate on the spreading of sovereign debt crisis from one Member State to other Member States facing similar conditions.

In this paper we analyse debt crises and debt stabilization strategies in a monetary union that features endogenous risk premia. Endogenous risk premia and their implications for debt stabilization are not well understood by economist and policy makers who are mostly trained to analyse debt stabilization in the linear -constant risk premium- framework (where many issues are already complicated enough). The non-linearities that endogenous risk premia introduce in the government debt dynamics complicate substantially the analysis. In particular, we analyse debt stabilization in two diametrically opposed regimes of endogenous risk premia.

In the first regime, the "national fiscal discipline regime", financial markets impose countries in a monetary union a sovereign risk premium based on the national government debt level only. This regime reflects the conventional idea that financial markets will act to discipline countries with deficits and debt dynamics that are (considered) unsustainable. In the context of the Eurozone, this regime assumes that the "no-bailout clause" is fully credible. The "no-bailout" clause was added to the European Union Treaty in order to address potential moral hazard/common pool problems where undisciplined Member States could shift in the end the consequences of their undisciplined policies to the other Member States.

$1 "$ The Union shall not be liable for or assume the commitments of central governments, regional, local or other public authorities, other bodies governed by public law, or public undertakings of any Member State, without prejudice to mutual financial guarantees for the joint execution of a specific project. A Member State shall not be liable for or assume the commitments of central governments, regional, local or other public authorities, other bodies governed by public law, or public undertakings of another Member State, without prejudice to mutual financial guarantees for the joint execution of a specific project." 
In the second regime, the "Eurobonds regime", financial markets impose on countries in the monetary union a risk premium based on the average debt level in the monetary union. The motivation of this regime is the perception that eventually the no-bailout clause may not be credible in an economically, politically and financially highly integrated area like the Eurozone. The Eurobonds regime assumes that there is -de facto or de jure- a form of complete sovereign debt mutualisation or federalisation. ${ }^{2}$ Less far reaching forms of Eurobonds can clearly also be envisaged see e.g. European Commission (2011) for a detailed analysis of Eurobonds. It is noted by the EU Commission that such a pooling of European debt would prevent the current adverse debt feedback effect on the risk premium, allowing the sovereign to get its debt back on a sustainable trajectory more easily. Also, Eurobonds would shelter Member States' sovereign debt from sudden shifts in risk aversion, unwarranted market volatility or animal spirits. Hence, by enabling member states to continually tap capital markets at a stable borrowing rate, a more resilient and less volatile debt trajectory should ensue. In our analysis of Eurobonds, sovereign debts of individual Member States become essentially non- distinguishable from each other in the eyes of financial markets, implying that all Member States face the same risk premium and which is related to the average debt level in the monetary union. We will assume throughout that in the Eurobonds regime the potential moral hazard problems have been tackled successfully, e.g. by imposing a set of comprehensive conditionalities.

The sovereign debt crisis has forced policy makers to implement new instruments to deal with the acute crisis situation. These measures in essence seek to remedy the weaknesses of monetary union in crisis situations, in particular the additional restrictions coming from monetary union outlined above. The actions that are most relevant for our analysis include: (i) the establishment in 2012 of a permanent institution, the European Stability Mechanism (ESM) that deals with crisis resolution by providing instant access to financial assistance programs for countries in the Eurozone in financial difficulty ${ }^{3}$, (ii) (De jure or de facto) negotiated haircuts on outstanding sovereign debt -in particular in the form of converting short-term debt obligations into long-term debt at reduced interest rates- were implemented in case of Greece and Cyprus e.g. ${ }^{4}$ (iii) the ECB's Outright Monetary Transaction (OMT) program that the ECB introduced in 2012 and which enables to purchase -under certain conditions- government debt issued by Eurozone countries. Between March 2015 and September 2016 (or even longer if necessary) the ECB intends to buy each month 60 bn euros worth of government bonds as part of its strategy to deal with the sovereign debt crisis and to stimulate the Eurozone economy/ stem deflation. This is clearly a sizeable monetary policy action in terms of increasing base and broad money. One other important aspect of (announcement of) such bondbuying programmes is their potential effects on stemming default expectations: in case the turmoil in sovereign is caused by sentiment/market expectations/speculation on default on sovereign debt, "self-fulfilling debt crises" may result. In that case -a la Calvo's (1988) analysis of government debt crises- default expectations rather than fundamentals are driving outcomes: rather than the "good" fundamentals-based equilibrium, a self-fulfilling "bad" equilibrium is produced. The bond-buy programme may avoid such outcomes as it stems default expectations as financial markets anticipate

\footnotetext{
${ }^{2}$ Steinbach (2015) draws parallels between the current Eurobonds discussion and US history where the decision in 1790 to introduce debt mutualisation and bailout acted as a cataclyst for fiscal federalism and fiscal union.

${ }^{3}$ The predecessor of the ESM, the European Financial Stability Facility (EFSF) was created as a temporary crisis resolution mechanism in June 2010. The EFSF has provided financial assistance -financed by issuing of bonds and other debt instruments in international capital markets- to Ireland, Portugal and Greece, the ESM has provided support to Spain and Cyprus.

${ }^{4}$ In April 2012 a deal was reached to restructure 210bn Greek government debt, imposing net present value (NPV) losses of 59 percent on its creditors (Zettelmeyer et al. (2013)).
} 
that solvency will be maintained, keeping market interests at manageable levels again.

We use numerical simulations of a number of relevant cases and compare outcomes in both regimes. We try to evaluate the sovereign debt crisis and the institutional weaknesses of a monetary union like the Eurozone and the proposed remedies indicated above. Our main policy relevant insight is that in the current discussions about fiscal union and Eurobonds, the effects of non-linearities in debt dynamics are not given enough consideration. These non-linearities change substantially government debt dynamics even in our simple model. Typically debt dynamics become more unstable by the non-linearities. We also find that in the presence of non-linearities policy changes could produce win-win or lose-lose outcomes for both high and low debt countries rather than win-lose arguments that often feature in discussions like the one about Eurobonds. Initial conditions also matter crucially: at high initial debt levels the non-linearities are much stronger mechanisms than at low debt levels. Eurobonds could contribute to flatten the average risk-premium induced nonlinearity in debt dynamics in a monetary union, contributing to stabilization of average government debt. Taken together, we conclude that the non-linearities are too important driving forces to be safely ignored by economists and politicians in their analysis of government debt stabilization and fiscal sustainability.

This paper is organised in as follows: Section 2 provides the analytical framework. Section 3 uses numerical simulations of a stylised example to illustrate the workings of the model and relate the results to the context of Europe's debt crisis and the current discussions about fiscal management in the Eurozone. Section 4 concludes.

\section{The Analytical Framework}

To analyse sovereign debt stabilization strategies in a monetary union context, we first construct and analytical framework that will then be used for numerical analysis. Consider a monetary union that consists of two countries, country 1 and 2 that set individual fiscal policies but share a common monetary policy that is operated by a common central bank that is called "ECB". The relative size of country 1 and 2 is denoted by $\omega, 1-\omega$, respectively. The accumulation of government debt is given by the dynamic government budget constraints that relates government debt, interest payments, monetary financing, primary fiscal deficits and stock-flow adjustments:

$$
\begin{gathered}
\dot{d}_{1}(t)=r_{1}(t) d_{1}(t)+f_{1}(t)-\frac{\theta}{\omega} m_{E}(t)+\overline{s f a}_{1}(t) \\
\dot{d}_{2}(t)=r_{2}(t) d_{2}(t)+f_{2}(t)-\frac{1-\theta}{1-\omega} m_{E}(t)+\overline{s f a}_{2}(t)
\end{gathered}
$$

in which $d_{i}, i=1,2$, denotes government debt in country 1 and 2 respectively, scaled to the level of national output (A dot above a variable refers to its time derivative). $r_{i}$ denotes the interest rate in country $i$ (adjusted for the rate of output growth in country $i$ which is assumed to be constant). $f_{i}$ the primary fiscal deficit, also scaled to output. Both countries receive a share $\theta, 1-\theta$ from the monetary financing $m_{E}$ undertaken by the ECB, measured as a fraction of aggregate output. Monetary finance includes seignorage "printing new money" and the increase in money supply as a result of open market operations or "bond-buying" of the ECB in government bond markets.

In August 2012 the ECB announced the start of conducting open market operations in secondary sovereign bond markets to safeguard an appropriate monetary policy transmission and preserve the singleness of its monetary policy. It announced a large scale and prolonged period of buying Eurozone 
sovereign debt. This with the aim of increasing banking sector liquidity and seeking thereby to increase bank lending to credit-constrained firms and households in the real economy. At the same it signalled to bond markets that the ECB will not stand aside, but will seek to avoid any sovereign debt defaults or bond market distress in the Eurozone. The technical features of the operations, named Outright Monetary Transactions, were announced in September 2012. Since countries may differ in size we need to rescale the share in the common base money growth, which each country is receiving, by its respective size when including this source of financing into the national government budget constraints.

The stock-flow adjustment $\overline{s f a_{i}}$ collects all measures/transactions outside the fiscal balance, that impact on the outstanding stock of debt, think e.g. the costly financial sector rescue packages that many EU countries had to construct to support the domestic financial sector at the fall-out of the global financial crisis, this were financed by additional borrowing. These stock-flow adjustments will remain exogenous variables in our model. We will use this variable to consider 'hair-cuts' on debt where creditors decide to agree to forgive a fraction of debt, and debt restructuring deals that reschedule debt repayments or other loan conditions in such a way that -effectively- debt relief occurs $^{5}$; finally also official rescue packages -like in the context of the European Stability Mechanismwhere countries can apply for temporary support in case of financial instability, take the form of a stock-flow adjustment.

It is important to note that the concept of fiscal sustainability is defined too vaguely in the literature to be meaningful for practical analysis. Sovereign debt crises result when fiscal sustainability is (expected to be) threatened. In practice, a distinction is made between liquidity and solvency crisis. A liquidity crisis results if countries experience short-term difficulties in meeting obligations while it can be assumed that they remain solvent and would be able to meet long-run obligations. Measures such as temporary rescue packages, increasing maturity of debt may suffice to overcome the liquidity crisis, whereas a solvency crisis implies that only debt-forgiveness or a default are the remaining options. Nevertheless, in practice one observes that liquidity crises precede or coincide with solvency crises. Theory imposes as a minimum requirement that the intertemporal solvency constraint is satisfied and Ponzi financing is ruled out. This requires that the current level of debt is not higher than the present value of the stream of future budgetary surpluses. This however does not result in specific constraints on debt and deficits at any point in time. Theory also does not define therefore what a sustainable debt threshold may be. ${ }^{6}$

Note that the growth adjusted interest rates vary over time and are highly uncertain. It can undergo unexpected and sharp variations due to shifts in risk appetites and the willingness to lend, thereby changing the debt dynamics in a fundamental way. The presence of risk premia result in a negative feedback between the debt ratio and the risk premium where an exogenous increase in sovereign spreads may trigger a perverse dynamics leading to "self-fulfilling solvency traps". Also primary fiscal balances may change rapidly as policy makers consider measures that change the fiscal stance. It is therefore, impossible to predict at which debt levels, lenders will stop lending to roll-over current debt and new debt without asking prohibitive compensation for the risk they assume to be

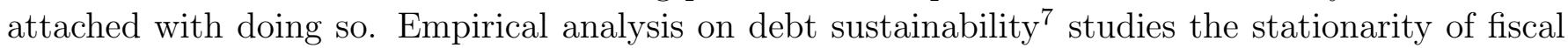

\footnotetext{
${ }^{5}$ The practice and history of haircuts on sovereign debt and debt restructuring is found in Cruces and Trebesch (2013).

${ }^{6}$ An interesting attempt to define such a threshold is provided by the Maximum Sustainable Debt level (and the associated probability of default at current debt levels of Collard et al. (2014). Still the approach requires to make explicit assumptions about the likely growth, interest rate and primary deficit trajectories.

${ }^{7}$ This large literature builds on the study by Hamilton and Flavin (1986).
} 
balance and co-integration between government spending and revenues: this may help to evaluate past trends but does not give guidance about fiscal sustainability in the near and longer term.

Policy makers, therefore have to rely on more practical approaches when assessing budgetary sustainability in real world. Most well-known is the Debt Sustainability Analysis framework used by the IMF and the World Bank that basically entails conducting stress tests in form of alternative scenarios with reference to a baseline projection scenario (see IMF (2003)) resulting in a set of debt burden thresholds that imply "low risk", "moderate risk", "high risk" and "debt distress". The EU's own debt sustainability Analysis framework (EU Commission (2014)) is related to the IMF approach. Among five aspects that could indicate vulnerability of fiscal sustainability, a 90 percent government debt to GDP ratio is proposed.

In our model, concern about fiscal sustainability is entered in a simple manner: fiscal policy makers in both countries set the fiscal primary fiscal deficit according to a fiscal rule that includes a debt feedback:

$$
f_{1}(t)=\bar{f}_{1}-\gamma_{1}\left(d_{1}(t)-\bar{d}_{1}\right), \quad f_{2}(t)=\bar{f}_{2}-\gamma_{2}\left(d_{2}(t)-\bar{d}_{2}\right)
$$

In other words, fiscal policy makers would like to keep the primary fiscal balance at some target level, $\bar{f}$ but correct the actual balance if the government debt level is moving away from its target $\bar{d}$. The strength of this feedback could be seen as measure of fiscal discipline. Fiscal rules are institutional mechanisms aiming to support fiscal credibility and discipline. The fiscal rules in (3) are clearly very stylized: in real world the issue of designing accurate fiscal rules is a complicated matter for policymakers. See e.g. IMF (2009) for a detailed analysis of the design and use of fiscal rules in practice and a review of literature. Interesting to note is that empirical estimates of fiscal rules, provide some indication about the value of $\gamma_{i}$ in practice as debt is mostly included as an explanatory variable, most studies find a relatively small but significant negative value.

Monetary policy in the monetary union is set by the common Central Bank according to a rule that relates the policy instrument money growth ("bond buying") to a target and the level of government debt in the monetary union as a whole. Again, this monetary policy rule is very stylized: in real world the design, implementation and effects of monetary policy rules is clearly a very complex issue, see e.g. Taylor and Williams (2010) for an overview. ${ }^{8}$

$$
m_{E}(t)=\bar{m}_{E}+\gamma_{E}\left(d_{a v g}(t)-\bar{d}_{E}\right)
$$

in which $d_{\text {avg }}(t)=\omega d_{1}(t)+(1-\omega) d_{2}(t)$ denotes the average debt level. Our analysis does not address the issue of credibility and uncertainty about monetary and fiscal policy rules, and the issue of strategic interaction between monetary and fiscal policy makers more generally. We assume instead that monetary and fiscal authorities simply operate their respective policy rules (based on full information and a context of perfect commitment). ${ }^{9}$

As noted in the introduction, sovereign risk premia are imposed by/reflect the workings of financial markets. Risk premia reflect the presence of default risk: the default probability rises, ceteris paribus, with rising debt, and the debt recovery rate in case of default falls as debt rises. Based on the expected governments' repayment behaviour, cq the expected debt recovery rate in case of default, investors

${ }^{8}(4)$ would actually be a form of McCallum's base money rule rather than the more common Taylor rule, in which case the monetary policy maker targets interest rates. Since our model includes risk premia the approach of (4) is a more appropriate choice here.

${ }^{9}$ See e.g. Eusepi and Preston (2011) on rule-based policies with uncertainty about monetary and fiscal policy regimes in terms of which player/rule is dominating, Engwerda et al. (2012) analyse the strategic interaction of monetary and fiscal policies in a framework related to the model in this paper. 
in government bonds set interest rates. Our simple model considers two diametrically opposed risk premia formation mechanism in the monetary union between Country 1 and Country 2. In the first case the "Fiscal Discipline (FD) regime" which is defined in (5), it is assumed that financial markets impose a risk premium based on each country's debt level separately.

$$
r_{1}(t)=\bar{r}_{1}+\alpha_{1} d_{1}(t), r_{2}(t)=\bar{r}_{2}+\alpha_{2} d_{2}(t)
$$

(5) implies that the no-bailout clause is credible and countries in the monetary union always have to address themselves a sovereign debt crisis as it assumed that bailout by other Member States of the monetary union will occur in case of an imminent default. Clearly, in reality many other factors than the debt level may impact on sovereign risk premia, think e.g. of political or social instability, economic growth, market sentiment, credit ratings, fiscal deficit announcements and external imbalances. Also debt maturity and other characteristics of debt matter: debt with long maturity carries more default risk than debt with very short maturities. This is also reflected in the observation that countries struggling with substantial sovereign debt burdens tend to have debt with a lower average maturity as creditors shy away from providing long term funding. The higher debt rollover associated with lower maturity debt generates a higher risk of liquidity squeezes as debtor countries are in continuous search for funding. In our theoretical model we abstract from these other determinants to focus on the debt-risk premium nexus. Empirical studies of risk premia,as e.g. Baldacci and Kumar (2010) demonstrate that the government debt level is one of the crucial determinants of sovereign bond risk premia. The empirical estimates for $\alpha$ in their literature overview are typically between 0.02 and $0.08 .^{10}$

Note that (5) could also be given an somewhat alternative interpretation that reflects the presence of a negative relation between output growth and the debt level since $r_{i}(t)$ measures the growthadjusted interest rate. In a much discussed study by Reinhart and Rogoff (2010) such a negative relation is tested for a broad set of developed countries, finding strong evidence of a non-linear negative relation between sovereign debt and economic growth. Other studies such as Herndon et al. (2014) question these results on theoretical or empirical grounds suggesting that such a relation between growth and the debt level is much smaller or absent. Here we prefer the interpretation that (5) reflects the increasing risk premia charged by financial markets to hold more sovereign debt as financial markets become more cautious about the risk of sovereign default.

In the second regime, the "Eurobonds (EB) regime" in (6), financial markets considers average sovereign debt in the union rather than individual country debt positions when setting risk premia.

$$
r_{1}(t)=\bar{r}_{1}+\alpha_{1} d_{a v g}(t), r_{2}(t)=\bar{r}_{2}+\alpha_{2} d_{a v g}(t)
$$

This regime reflects the case were the no-bailout clause is no longer credible and (it is assumed that) in one way or another support of other countries in the monetary union will be available in case default on bonds of the high debt country would occur. ${ }^{11}$ In this paper we do not explore

\footnotetext{
${ }^{10}$ Note that a more complex functional form of $(5)$ could be chosen: a quadratic risk premium function $r_{i}(t)=$ $\bar{r}_{i}+\alpha_{i} d_{i}(t)+\beta_{i} d_{i}(t)^{2}$ would imply a cubic debt adjustment equation (7) making debt dynamics even more unstable than in the linear risk premium case.

${ }^{11}$ The literature at least since the seminal work of Eaton and Gersovitz (1981) distinguishes "excusable" (unintended, unavoidable) default from "strategic" default (where borrowers strategically default as soon as the benefits from doing so exceed costs. Among the costs from sovereign default stand in particular the reputation loss, a partial or full exclusion from the capital market for a significant period and the likely fall-out on the real economy). We do not strictly distinguish between both when we consider sovereign debt crises in the context of our simple model.
} 
the argument that is often advanced against Eurobonds that it would give wrong incentives to undisciplined fiscal authorities that would no longer feel the disciplining force of financial markets ${ }^{12}$ but obviously acknowledge the need to design proper incentive schemes if a form of Eurobonds would be introduced in practice.

One other remark concerning the risk premia formation is useful. In the context of Europe's sovereign debt crisis, the risk of "contagion" has been often noted: countries with high debt and risk premia may "infect" also other Member States with sound public finances as financial markets anticipate that a default of high debt countries will have large effects for the other countries as well. In a "flight to quality" investors could drop bonds of all "infected" countries. In the context of our model this could be analysed by introducing a risk premium mechanism which implies that risk premia of all countries are driven by the debt level of the country with the highest sovereign debt (so $r_{i}(t)=\bar{r}_{i}+\alpha_{i} d^{H I G H}(t)$ where HIGH refers to the country with the highest debt level in the monetary union instead of (5) or (6)). For an account of possible contagion in European sovereign debt markets during the debt crisis see e.g. Arghyrou and Kontonikas (2011) who find evidence of contagion of Greek government debt risk premia on other peripheral Eurozone countries. In a study for the pre-crisis period Skintzi and Refenes (2006) define both price and volatility spillovers in EU bond markets and between EU and US bond markets. These spillovers act as a measure of integration and form also an indication of potential of contagion. It is found that spillovers are substantial in particular in terms of volatility.

Both regimes of risk premium formation (5) and (6), result in non-linear debt dynamics -and therefore non-linear dynamics of interest rates, fiscal deficits and money growth-. In general no analytical results can be obtained about non-linear dynamic systems. In the specific case chosen here where the risk premia are a linear function of either national or union-average debt level, debt dynamics are quadratic. Clearly the initial debt level is very important: at low debt levels the nonlinearities will not be very substantial, at high debt levels the strength of non-linearities becomes a dominant driving forces, that makes debt dynamics increasingly unstable.

The debt dynamics in case of the FD regime result from combining (1)-(5) into the following (first-order non-homogeneous) quadratic differential equation:

$$
\begin{array}{r}
{\left[\begin{array}{c}
\dot{d}_{1}(t) \\
\dot{d}_{2}(t)
\end{array}\right]=\left[\begin{array}{cc}
\bar{r}_{1}-\gamma_{1}-\theta \gamma_{E} & -\theta \gamma_{E} \frac{1-\omega}{\omega} \\
-(1-\theta) \gamma_{E} \frac{\omega}{1-\omega} & \bar{r}_{2}-\gamma_{2}-(1-\theta) \gamma_{E}
\end{array}\right]\left[\begin{array}{c}
d_{1}(t) \\
d_{2}(t)
\end{array}\right]} \\
+\left[\begin{array}{cc}
d_{1}(t) & 0 \\
0 & d_{2}(t)
\end{array}\right]\left[\begin{array}{cc}
\alpha_{1} & 0 \\
0 & \alpha_{2}
\end{array}\right]\left[\begin{array}{l}
d_{1}(t) \\
d_{2}(t)
\end{array}\right]+\left[\begin{array}{l}
\bar{b}_{1} \\
\bar{b}_{2}
\end{array}\right]
\end{array}
$$

in which $\bar{b}_{1}=\bar{f}_{1}+\gamma_{1} \bar{d}_{1}-\frac{\theta}{\omega} \bar{m}_{E}+\frac{\theta}{\omega} \gamma_{E} \bar{d}_{E}+\overline{s f a}_{1}$ and $\bar{b}_{2}=\bar{f}_{2}+\gamma_{2} \bar{d}_{2}-\frac{1-\theta}{1-\omega} \bar{m}_{E}+\frac{1-\theta}{1-\omega} \gamma_{E} \bar{d}_{E}+\overline{s f a_{2}}$ The quadratic debt dynamics in case of the EB regime are described by a similar differential equation, resulting from (1)-(4) and (6) :

$$
\begin{array}{r}
{\left[\begin{array}{c}
\dot{d}_{1}(t) \\
\dot{d}_{2}(t)
\end{array}\right]=\left[\begin{array}{cc}
\bar{r}_{1}-\gamma_{1}-\theta \gamma_{E} & -\theta \gamma_{E} \frac{1-\omega}{\omega} \\
-(1-\theta) \gamma_{E} \frac{\omega}{1-\omega} & \bar{r}_{2}-\gamma_{2}-(1-\theta) \gamma_{E}
\end{array}\right]\left[\begin{array}{c}
d_{1}(t) \\
d_{2}(t)
\end{array}\right]} \\
+\left[\begin{array}{cc}
d_{1}(t) & 0 \\
0 & d_{2}(t)
\end{array}\right]\left[\begin{array}{ll}
\alpha_{1} \omega & \alpha_{1}(1-\omega) \\
\alpha_{2} \omega & \alpha_{2}(1-\omega)
\end{array}\right]\left[\begin{array}{l}
d_{1}(t) \\
d_{2}(t)
\end{array}\right]+\left[\begin{array}{l}
\bar{b}_{1} \\
\bar{b}_{2}
\end{array}\right]
\end{array}
$$

\footnotetext{
${ }^{12}$ In terms of the model, this would suggest that the Eurobonds regime would lead to a reduction in the $\gamma$ parameter in the fiscal rule.
} 
It is important to note that in case countries are completely symmetric and start from the same initial debt level, both regimes are identical. ${ }^{13}$ Of course also if $\alpha$ is approaching 0 , both cases will converge to each other since risk premia in that case will be reduced to the constant part $\bar{r}$ and the dynamics of (7) and (8) reduce to a set of linear differential equations (whose analytical solution is evaluated in the Appendix as it serves as a useful reference point for the numerical analysis in the next section).

In order to evaluate welfare losses of the fiscal authorities we will use the following quadratic loss functions:

$$
\begin{aligned}
& L_{1}(t)=\frac{1}{2} \int_{0}^{T}\left\{\left(f_{1}(t)-\bar{f}_{1}\right)^{2}+\beta_{F 1}\left(d_{1}(t)-\bar{d}_{1}\right)^{2}\right\} e^{-\delta_{1} t} d t \\
& L_{2}(t)=\frac{1}{2} \int_{0}^{T}\left\{\left(f_{2}(t)-\bar{f}_{2}\right)^{2}+\beta_{F 2}\left(d_{2}(t)-\bar{d}_{2}\right)^{2}\right\} e^{-\delta_{2} t} d t
\end{aligned}
$$

Fiscal authorities in other words are concerned about stabilizing the (primary) budgetary deficit and government debt in their own countries. The ECB is concerned about money growth and debt stabilization in the monetary union as a whole. As a consequence, the objective function of the ECB is given by

$$
L_{E}(t)=\frac{1}{2} \int_{0}^{T}\left\{\left(m_{E}(t)-\bar{m}_{E}\right)^{2}+\beta_{E}\left(d_{a v g}(t)-\bar{d}_{E}\right)^{2}\right\} e^{-\delta_{E} t} d t
$$

$\beta$ indicates the relative preferences of the fiscal authorities and the CB concerning debt stabilization in the MU as a whole, whereby fiscal authorities consider national debt and the ECB average debt in the monetary union. From the loss functions, combined with the policy rules (we see that three factors determine very much welfare losses: (i) the relative weights given to debt stabilization (ii) the target values for debt, deficit and money growth, (iii) the initial conditions wrt government debt).

\section{$3 \quad$ Numerical Results}

In this section, we use numerical analysis to explore the most important aspects of the model, and in particular relating to the two different mechanisms relating to the formation of risk premia in the monetary union. After outlining a baseline scenario we analyse the effects of changes in fiscal discipline (Scenario 1), haircuts on current debt (Scenario 2), a bond-buying programme of the Central Bank (Scenario 3), a official sector bailout/rescue programme (Scenario 4).

\subsection{A symmetric monetary union and the effects of initial debt differ- ences}

Point of departure is a symmetric baseline setting where countries are of equal size and receive a proportional share of ECB money growth, $\theta=\omega=0.5$. Concerning the fiscal policy rules (3), the primary fiscal deficit targets are balanced primary budgets: $\bar{f}_{1}=\bar{f}_{2}=0.0$, while the government debt targets equal 60 percent of GDP $\bar{d}_{1}=\bar{d}_{2}=0.6$, the debt stabilization weights are set equal to $\gamma_{1}=\gamma_{2}=0.1$. Similarly, the common monetary policy rule (4) features a money growth target of 0 percent, $\bar{m}_{E}=0$, a debt target of 60 percent of GDP, $\bar{d}_{E}=0.6$ and the debt stabilization weight

\footnotetext{
${ }^{13}$ From (7)and (8) it is seen that the differences between the two regimes are determined by the $\operatorname{term}\left[\begin{array}{cc}d_{1}(t) & 0 \\ 0 & d_{2}(t)\end{array}\right]\left[\begin{array}{cc}\alpha_{1}(1-\omega) & -\alpha_{1}(1-\omega) \\ -\alpha_{2} \omega & \alpha_{2} \omega\end{array}\right]\left[\begin{array}{l}d_{1}(t) \\ d_{2}(t)\end{array}\right]$.
} 
equals $\gamma_{E}=0.1$. In the risk premia formation mechanisms (5) and (6), the risk-free interest rate (corrected for growth) equals 1 percent, $\bar{r}_{1}=\bar{r}_{2}=0.01$. We assume that the risk-premium parameter that measures the sensitivity wrt the debt levels equals $\alpha_{1}=\alpha_{2}=0.065$ which implies a substantial non-linearity in the debt dynamics. Finally, in the loss functions (7)-(9) the discount factors are set to $\delta_{1}=\delta_{2}=\delta_{E}=0.01$ and the weights on debt stabilization equal: $\beta_{F 1}=\beta_{F 2}=\beta_{E}=0.05$. The only difference between country 1 and 2 concerns the initial debt level: high debt country 2 starts with a double initial debt level of the low debt country 1 (who's initial debt equals the debt target): $d_{1}(0)=0.6$ while $d_{2}(0)=1.2$.

The debt - (first row), risk premium - (second row), and deficit and money growth dynamics (third row) that result in this baseline case are displayed in Figure 1. In the first (second) column the results in case of the FD (EB) regime are given, while the third column graphs the difference (FD-EB) between both regimes. Debt, risk premium and deficit of country 1 (2) are indicated by blue (green) lines, average debt, average risk premium and money growth are indicated by red lines.
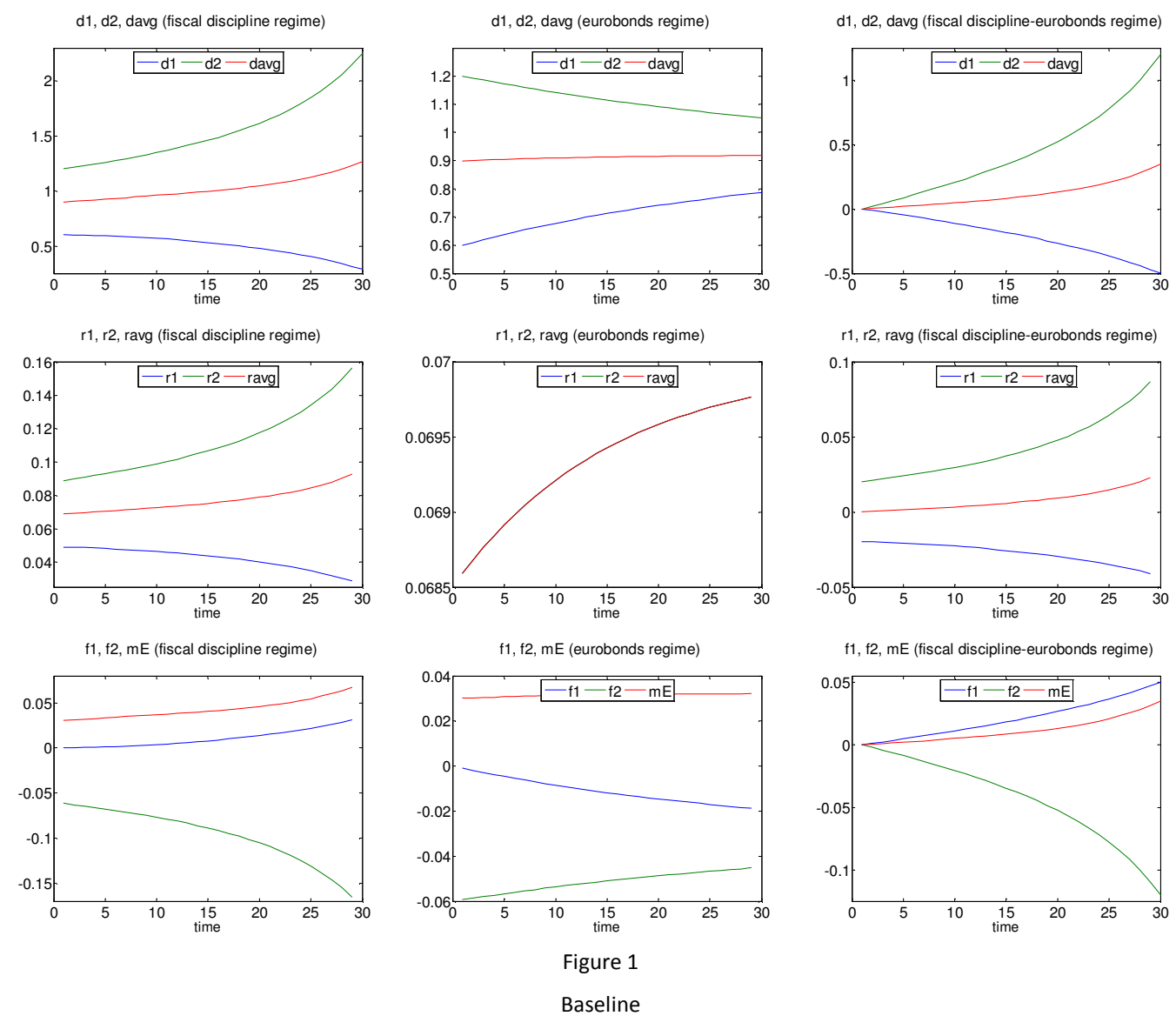

The monetary union is confronted with a looming sovereign debt crisis in country 2 in the FD regime: without changes in its conditions, its debt is growing without bound. Its risk premium is increasing along. Its efforts in the form of an increasing budgetary surplus (a negative deficit $f_{2}(t)$ ) are 
insufficient to achieve debt stabilization. Country 1's debt is actually declining in the long-run from its already low level. In the EB regime (second column) outcomes are very different. Country's 2 debt is now stabilized, while country 1 sees increasing debt as interest rate burdens are in a way redistributed: Country 1 borrows at a somewhat higher rate than in the FD regime, while country 2 benefits from a significantly lower interest rate. Because of the non-linearity this increase of the interest rate of country 1 is smaller than the decrease experienced by Country 2 so that on average risk premia, debt and deficits are lower in the EB regime. Column 3 illustrates this important aspect: the non-linearity in risk premia implies that the change from the FD to the EB regime is not neutral, it is more than a mere redistribution of debt stabilization burdens between countries. Moving to the EB regime is not a zero-sum game in other words. Average debt, risk premia and deficits are lower and money growth is higher (c.q. surpluses are smaller) in the EB regime than in the FD regime.

The welfare losses associated with the dynamics of debt, deficits and money growth of this baseline case are found in Table 1 first line, (the welfare losses for Case 2-5 that contain changes to the baseline setting are also given in Table 1). We find that in this baseline case all players experience lower losses in the EB regime (this also holds for Case 2-5 hereafter with one exception Country 1 in Case 3 and Case 5 would not benefit from the EB regime). The underlying reason is that the non-linearity in the average debt dynamics (the "average debt non-linearity") is less strong in the EB regime. In particular, Country 2 benefits: it has a much lower risk premium in the EB regime as it can borrow at a risk premium that reflects average debt in the monetary union and avoid a government debt crisis. Also Country 1 and the common Central Bank benefit from the Eurobonds and the reduction of debt in Country 2.

\begin{tabular}{|c|c|c|c|c|c|c|c|}
\hline & & $\begin{array}{l}L_{F 1} \\
\mathrm{FD}\end{array}$ & $L_{F 2}$ & $L_{E}$ & $\begin{array}{l}L_{F 1} \\
\mathrm{~EB}\end{array}$ & $L_{F 2}$ & $L_{E}$ \\
\hline Case 1 & baseline & 13.03 & 587.57 & 107.48 & 1.87 & 20.43 & 8.20 \\
\hline Case 2 & $\bar{f}_{2}=0.01$ & 50.19 & 8081.8 & 1855.7 & 1.13 & 31.23 & 10.83 \\
\hline Case 3 & $s f a_{2}=-0.2$ & 0.43 & 48.16 & 10.77 & 2.67 & 13.56 & 6.75 \\
\hline Case 4 & $\bar{m}_{E}=0.02$ & 4.40 & 58.86 & 9.78 & 0.38 & 12.99 & 4.84 \\
\hline Case 5 & $s f a_{2}=-s f a_{1}=-0.2$ & 1.45 & 26.25 & 9.46 & 5.06 & 12.43 & 8.20 \\
\hline
\end{tabular}

Table 1 Welfare losses in alternative scenarios

\subsection{Effects of differences in fiscal discipline}

An important underlying determinant of debt dynamics is the (lack of) degree of fiscal discipline. Fiscal discipline is indeed one of the crucial components of the Eurozone's Stability and Growth Pact (including the successive amendments and extensions of the original framework). It is interesting to consider in our model the effects -compared to our baseline outlined in Section 3.1- of differences in fiscal discipline between country 1 and 2 and the consequences thereof in the two regimes of risk premium formation. In this second simulation, we therefore reduce the amount of fiscal discipline in Country 2: we set the primary fiscal deficit target to 1 percent: $\bar{f}_{2}=0.01$ in the fiscal balance rule (3), while we keep the same parameter in the case of country 1 as in the baseline: $\bar{f}_{1}=0$. 

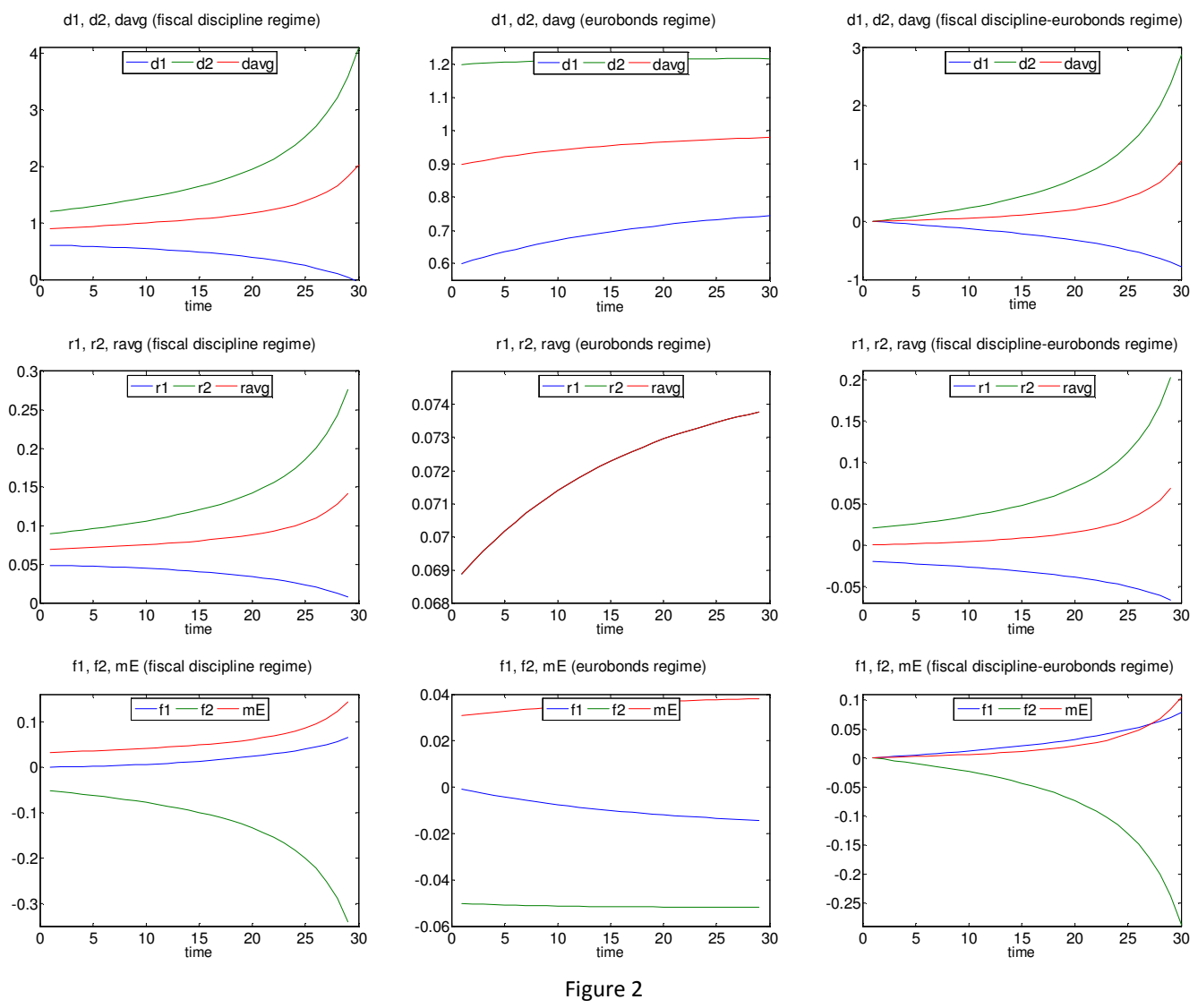

Lower fiscal discipline Country 2

Country 2 therefore starts with a high debt level and faces now also a problem with maintaining fiscal discipline. Note that instead of associating an increase in $\bar{f}$ also a reduction in $\tau_{F}$ implies less fiscal discipline as it reduces the debt-sensitiveness of the fiscal policy instrument. Results in case of reducing $\gamma_{i}$ are therefore comparable to the effects of an increase in the deficit target $\bar{f}_{i}$ in Figure 2 . In the FD regime, debt and risk premium in Country 2 rapidly deteriorate: Country 2 faces an sovereign debt crisis. While not involved directly, note that Country 1's debt and risk premium actually decline compared to the baseline. The reason is that the additional money growth due to high debt in Country 2 is shared between both countries: this reduces debt in Country 1 . In the EB regime we observe that the changes compared to the baseline Case 1 are smaller than in the FD regime. This is again a reflection of the non-linearities in the risk premium. While Country 2 is less disciplined than before, the consequences thereof are much smaller in the EB regime where Country 2 now can borrow against the average risk premium, and even benefiting from lower borrowing of Country 1. Lower fiscal discipline in the high debt country, results in higher differences between both regimes. 


\subsection{Effects of haircut on country 2 debt}

A unilateral or negotiated (partial) default or haircut on government debt is clearly the most drastic -but sometimes unavoidable- measure to address a government debt crisis. Usually a default is followed by a period where countries will lack access to capital markets to finance new loans. Once in default, restructuring strategies can be negotiated by governments and creditors. Sovereign debt restructuring programs can take any form depending on the outcomes of negotiations betweens debtor countries and commercial or official creditors.

Typically, agreement about the timing, size of a haircut on current debt and support to an orderly return to normal lending conditions in capital markets are part of a debt restructuring program. Timing of default and debt restructuring has been analysed in a dynamic model of sovereign default by Bi (2008) who shows that a waiting-for-a-larger-cake consideration by creditors and debitors results in delays during the debt renegotiation process, and that these delays can help explain the observed volatility of sovereign bond spreads. In the model of Pitchford and Wright (2012) debt restructuring negotiations are delayed as free-riding behaviour of individual creditors seeking to extract greater payments from the sovereign, holds up a settlement. ${ }^{14}$

Debt restructuring -including debt-forgiveness- is efficient in case of debt overhang where debt restructuring contributes to regain growth and capacity to repay. In that case, debt restructuring would even be in the interest of creditors since the debt-Laffer curve relation would predict that the market value of outstanding debt would actually rise after the restructuring. This logic was also implicit in the initiatives since the end of the 1980s where heavily indebted low-income countries (LICs) have been benefiting from debt relief measures that range from the rescheduling of interest payments to debt forgiveness, well-known measures are the Heavily Indebted Poor Countries (HIPC) Initiative of 1996 and the Multilateral Debt Relief Initiative (MDRI) of 2005. Also the three Economic Adjustment Programme for Greece $(2010,2011,2015)$ that imply substantial debt restructuring, have been accompanied by an agreement with banks to accept a 50 percent write-off of (some part of) Greek debt and economic reforms to reinvigorate growth. Such an effect will also be present in our small model: the haircut will reduce the initial debt level and thereby the (growth) adjusted interest rate rendering debt dynamics more stable.

Typically, agreement about the timing, size of a haircut on current debt and support to an orderly return to normal lending conditions in capital markets are part of a debt restructuring program. Timing of default and debt restructuring has been analysed in a dynamic model of sovereign default by $\mathrm{Bi}$ (2008) who shows that a waiting-for-a-larger-cake consideration by creditors and debitors results in delays during the debt renegotiation process, and that these delays can help explain the observed volatility of sovereign bond spreads. In the model of Pitchford and Wright (2012) debt restructuring negotiations are delayed as free-riding behaviour of individual creditors seeking to extract greater payments from the sovereign, holds up a settlement. ${ }^{15}$

Figure 3 displays the effects of a 20 percent haircut on country 2 its debt in period 1 (i.e. $\left.\overline{s f a}_{2}(1)=-0.2\right)$.

\footnotetext{
${ }^{14}$ For details on the practice and history of debt restructuring and haircuts on sovereign debt see Cruces and Trebesch (2013) and Erce (2013). Trebesch (2009) analyses the effects of sovereign debt restructurings on the domestic private sector. It is found that restructuring policies that are more "aggressive" towards creditors are more harmful to the domestic private sector that is more strongly deprived of foreign credit after the sovereign default.

${ }^{15}$ For details on the practice and history of debt restructuring and haircuts on sovereign debt see Cruces and Trebesch (2013) and Erce (2013). Trebesch (2009) analyses the effects of sovereign debt restructurings on the domestic private sector. It is found that restructuring policies that are more "aggressive" towards creditors are more harmful to the domestic private sector that is more strongly deprived of foreign credit after the sovereign default.
} 

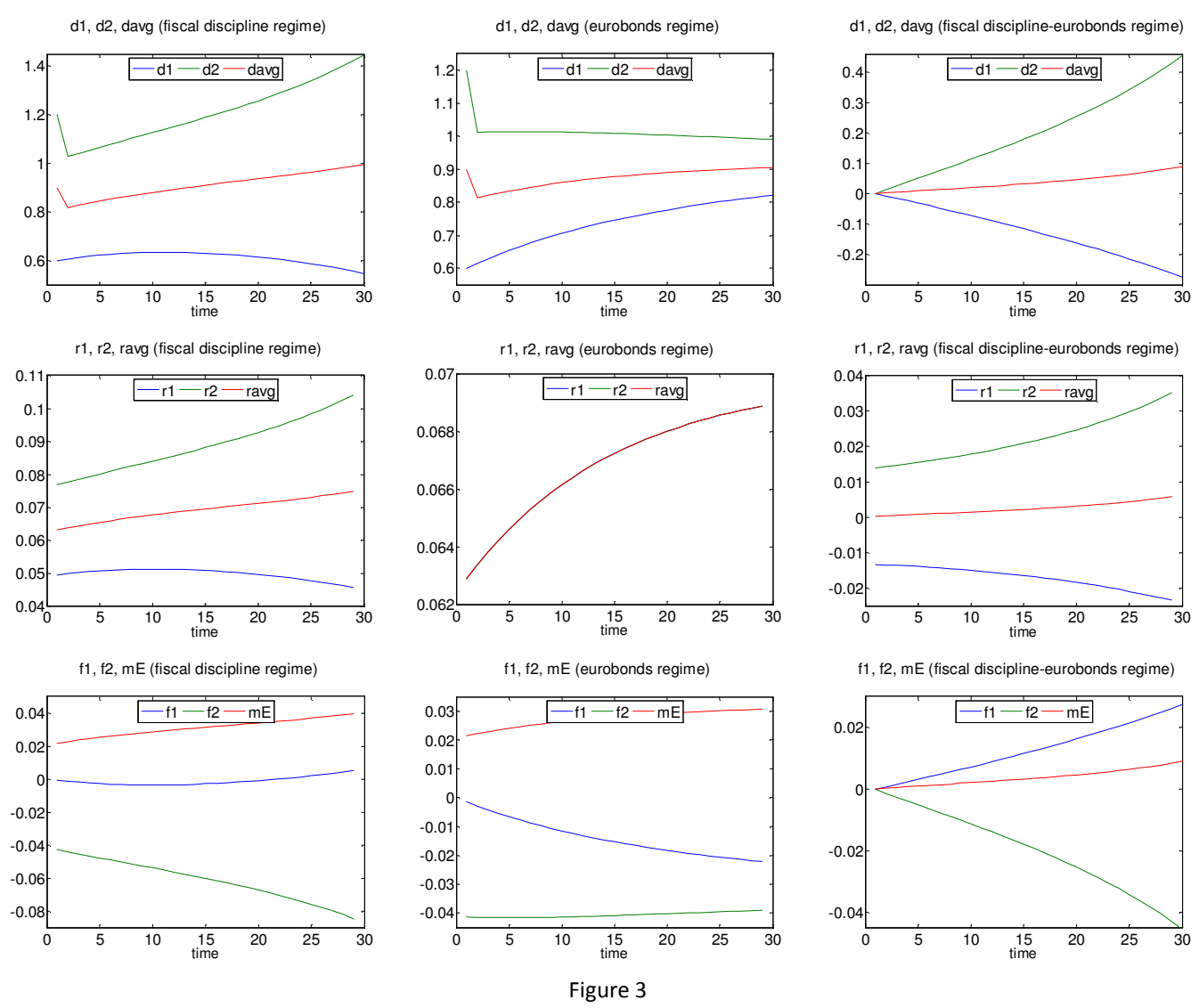

A haircut on Country 2 debt

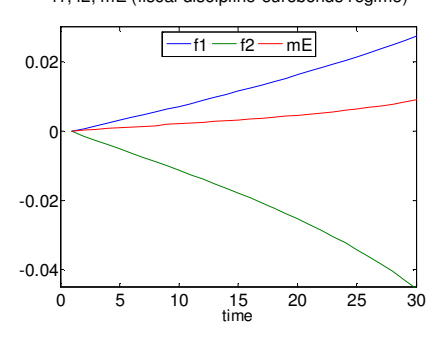

A substantial haircut produces of course a lower path/pace of debt accumulation for Country 2, implying lower risk premia and a lower surplus and money growth (in both the FD and EB regime). However, the haircut itself mainly buys time, it does not alter the underlying unstable dynamics of Country 2 in the FD case. Therefore, debt restructuring in real world is often accompanied by accompanying measures that aim at strengthening fiscal discipline (i.e. increasing $\gamma$ in the context of our model) and reforming the economy to foster growth (i.e. raising $\bar{r}$ which is the growth-adjusted risk-free interest rate in the model). If successful, such reforms contribute to flatten debt dynamics as they address the underlying determinants of fiscal sustainability. Note also that the introduction of Eurobonds is such a measure that concerns the fundamental determinants (here by changing the non-linearity in the risk-premium formation). As we noted already in the baseline, introducing Eurobonds would succeed in stabilising Country 2's unstable debt dynamics. 


\subsection{Effects of an increase in buying sovereign debt by the common mon- etary central bank}

The recent financial and sovereign debt crisis has led to large bond-buying programs as Central Banks across the globe try to increase liquidity of banks and stem deflation and recession in this manner. While still considerable uncertainty remains about the effectiveness of such large Central Bank bond-buying programmes, one important effect is highly relevant in the context of our model: the increase in the (base) money supply that results. To gain insight on the effects of bond-buy programme by the common Central Bank, Case 4 simulates the effects in Figure 4 of an increase in the common money supply growth that results if the common Central Bank becomes more sensitive to the issue of average sovereign debt stabilization. In that case, $\gamma_{E}$ increases to 0.15 (compared to the baseline value of 0.1 , note that similar effects are produced by an increase in the money growth target, $\left.\bar{m}_{E}\right)$.
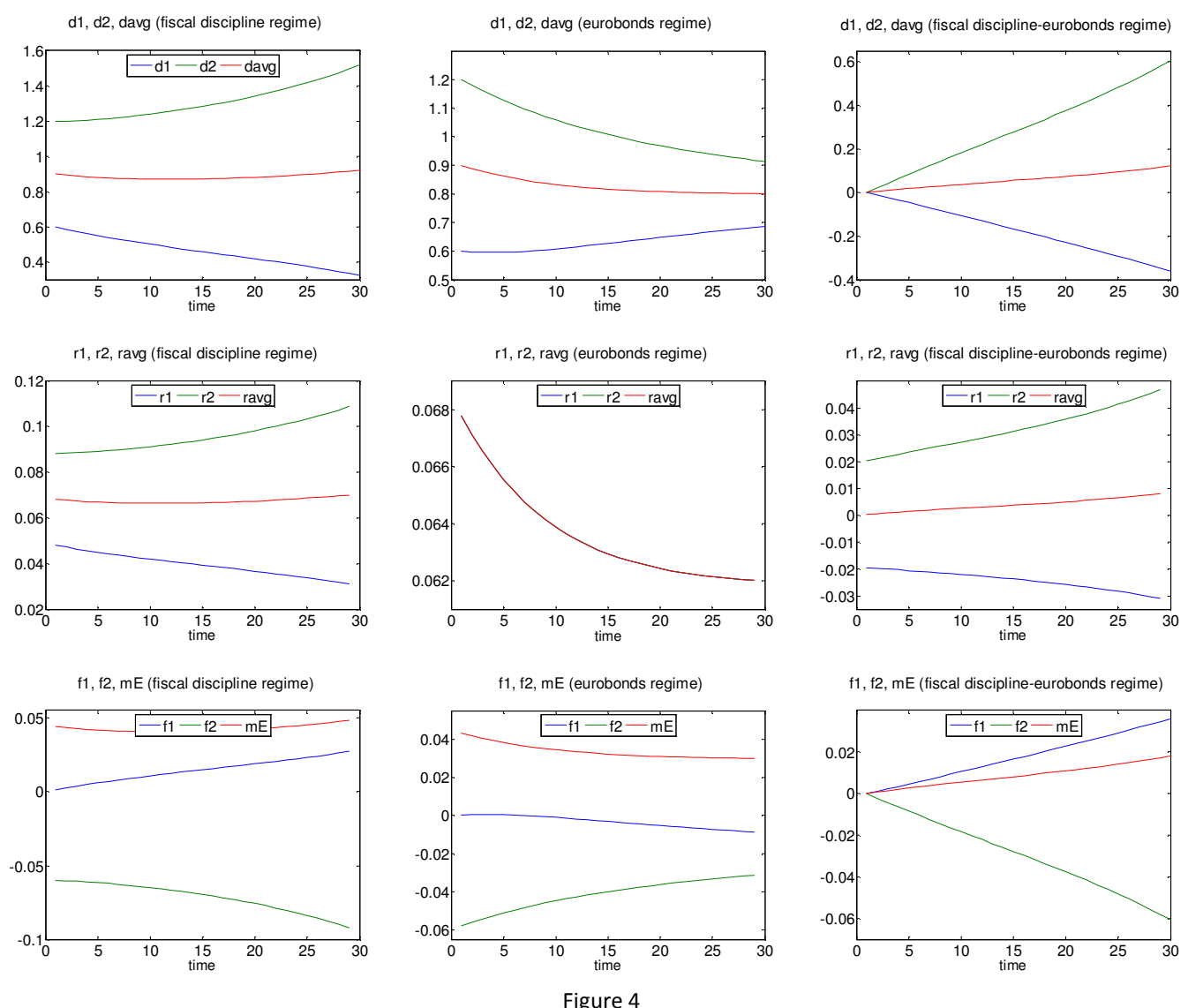

An increased government bond buying program of the common Central Bank

It is clear that this monetary policy change has a strong impact on debt, risk premium and deficit dynamics for both countries and money growth in both regimes. As noted earlier, because of the 
non-linear mechanism in the risk premium, effects (compared to the baseline) are strongest for the high debt country 2 and in the FD case. Country's 2 debt is now almost stabilized in the FD regime and declines in the EB regime. Compared to the baseline, fiscal deficits are higher/fiscal surpluses are smaller as the fiscal authorities take a smaller share in the adjustment burden relating to debt stabilization in case the monetary authority takes a larger share. Note here also the reduction of risk premia and therefore interest burden compared to the baseline scenario.

\subsection{Official sector bailouts: Debt relief country 2 from a rescue package financed by country 1}

In Case 3 a haircut on Country 2's debt was carried out. Implicitly it was assumed that the haircut was forced upon/agreed with anonymous (international) sovereign debt investors, e.g. after a process of sovereign debt restructuring. Debt relief Country 2 could also come from a rescue package financed by Country 1. One reason to do so, could be that Country 1 would also be greatly affected by an eventual complete default by Country 2, in particularly by the resulting financial turmoil and the possibility of contagion. In extremis the existence of the entire monetary union may be endangered by a sovereign default of Country 2. We assume that such a form of crisis resolution mechanism/official sector bailout assumes the presence of international solidarity. It is often pointed out that official sector financial sector support -e.g. like provided by the IMF or ESM- risks to create moral hazard problems as sovereign borrowers may choose as a result strategies that imply excessive risk taking or delay painful but unavoidable policy changes. Here, we abstract from such moral hazard issues: in our simple model these could be modelled as a simultaneous reduction of $\tau$ if a bailout is reached, the sensitiveness of the fiscal balance to the debt level. In Figure 5 we analyse the same haircut as in Case 3 but now Country 1 is assumed to provide the financial assistance (i.e. $\overline{s f a}_{2}(1)=-0.2=-\overline{s f a}_{1}(1)$ ) . 

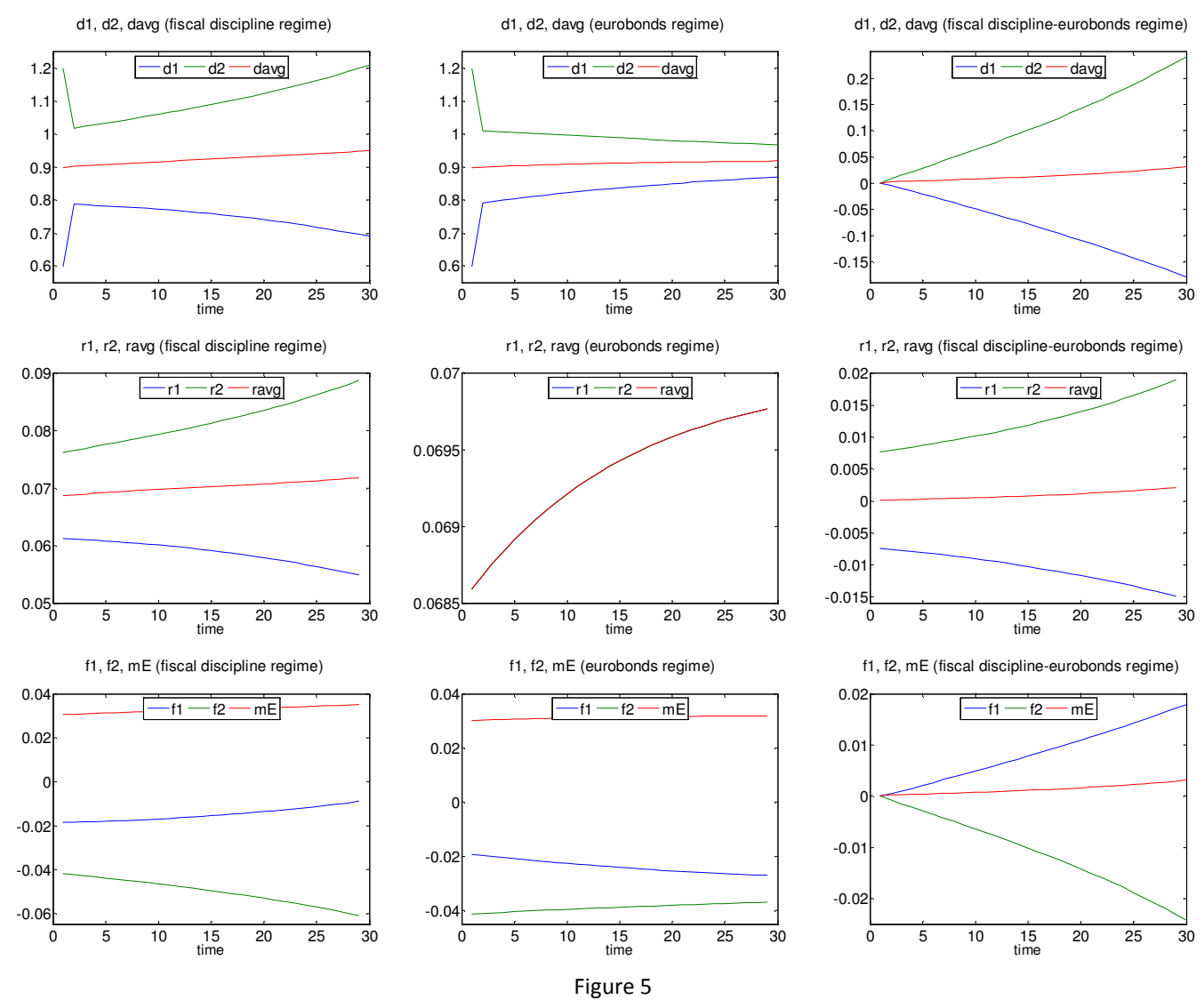

A Country 2 bailout by Country 1

This financial assistance programme for Country 2 implies therefore that total debt in monetary union is not reduced as in Case 3 but merely redistributed between Country 2 and Country 1. The haircut implies -even more than in Case 3- that initial debt positions are brought closer together. Because of the non-linearity in risk premia, even such a mere redistribution still has important effects. The divergence in debt and deficits between Country 1 and 2 is therefore the lowest of all Cases studied. This holds both in case of the FD and the EB regime. Also the differences between the FD and EB (third collumn of Figure 5) are the smallest in this Case: because of the initial redistribution of debt that is effectively implied by the bailout of Country 2 by Country 1 the effect of introducing EB is reduced (in extremis where a complete equalization of initial debt levels would be implemented -and countries remain symmetric in all other parameters as in our baseline-), the $\mathrm{EB}$ and $\mathrm{FB}$ regime would start to result in the same outcomes).

Our example assumed (implicitly) that Country 2 is not able/willing/required to refund the financial assistance to country 2 later on. Aim of official sector bailouts is typically to restore indebted countries' repayment capacities and international credibility. To achieve this the rescue programmes include structural reform and fiscal restructuring guidelines/conditions. If indeed successful, countries 
would be able at the end of the program to reimburse the emergency assistance (in full or partly). In the setting of numerical example this would imply that the initial transaction is reversed at the end of the program: Country 2 would reimburse Country 1 for the initial transaction. Debt in Country 1 (2) would decline (increase) with this amount, increasing debt divergence again.

\section{Conclusion}

Sovereign debt crises can hit countries when confronted by adverse shocks in the real economy or financial sector that cause a budgetary deficit and increase in government debt accumulation. Lack of confidence in budgetary sustainability by financial markets can lead to additional instability as risk premia increase substantially. These mechanisms concern both monetary union and non-monetary union countries. However, countries in a monetary union like the Eurozone, typically are confronted with set of additional institutional constraints that may hinder countries to address the causes and effects of a sovereign debt crisis. In this paper, we address the question how the introduction of Eurobonds would affect outcomes in a monetary union. The Eurobonds here imply a design where all sovereign debt is issued under a full, joint and several guarantee from all other participating member states. This implies that every participating country can be held responsible up to the reimbursement of the claimants, should the original obligor default. Other, less far reaching Eurobonds can also be envisaged in real world but not explored in our analysis.

Using numerical analysis, we analysed several important aspects relating to sovereign debt stabilization in a monetary union. We found that the non-linearity in risk premia implies that the change from the "Fiscal Discipline" to the "Eurobonds" regime is not neutral, so that introducing Eurobonds is more than a mere redistribution of adjustment burdens from debt stabilization between countries; moving to the EB regime is not a zero-sum game if one likes. Compared with the Fiscal Discipline regime, the Eurobonds regime -that entails essentially government debt mutualisation and therefore shared responsability in a monetary union- implies that the non-linearities in government debt dynamics from risk premia are flattened for high debt countries, while the debt dynamics for low debt countries increase somewhat. It is important to stress that due to the non-linearity in debt dynamics from risk premia, a flattening of average government debt dynamics in a monetary union results as the non-linearities affect much stronger the high debt country than the low debt country. A net gain would result from moving to Eurobonds -at least according to this theory argument and assuming that potential negative incentive effects are properly dealt with-. Introducing Eurobonds would lead to lower average debt in the monetary union rather than to higher average debt as is often implicitly assumed in policy discussions about forms of debt mutualisation in monetary unions.

In addition, if one takes an insurance perspective on participating in a monetary union, debt mutualisation in form of Eurobonds is also an interesting option. Even a country with currently a low level of debt may find debt mutualisation useful: it may well find itself in the future in a high debt state, due to a negative economic or financial shock e.g. (similarly, a high debt country may be in a lower debt state at some future point in time). Eurobonds in that case act as a shock absorber and preventing countries from seeing adjustment burdens further increased from high risk premia that will occur in the no-Eurobonds regime. 


\section{References}

Arghyrou, M., and A. Kontonikas (2011), The EMU Sovereign-Debt Crisis: Fundamentals, Expectations and Contagion, European Commission, Economic Papers No.436.

Baldacci, G., and M. Kumar (2010), Fiscal Deficits, Public Debt, and Sovereign Bond Yields, IMF Working Paper 10/184.

Bi, R. (2008), Beneficial Delays in Debt Restructuring Negotiations, IMF Working Paper 08/38.

Calvo, G. (1988), Servicing the Public Debt: The Role of Expectations, The American Economic Review, vol.78(4), p.647-661.

Checherita, C., and P. Rother (2012), The Impact of High and Growing Government Debt on Economic Growth: An empirical Investigation for the Euro Area, European Economic Review, vol.56(7), p.1392-1405.

Collard, F., M. Habib and J. Crochet (2014), Sovereign Debt Sustainability in Advanced Economies, mimeo.

Cruces, J. and C. Trebesch (2013), Sovereign Defaults: The Price of Haircuts, American Economic Journal: Macroeconomics, vol.5(3), p. 85-117.

Engwerda, J., B. van Aarle, J. Plasmans, and A. Weeren (2013), Debt Stabilization Games in the Presence of Endogenous Risk Premia, Journal of Economic Dynamics and Control, Vol.37, p.25252546.

Eaton, J. and M. Gersovitz (1981), Debt with Potential Repudiation: Theoretical and Empirical Analysis, Review of Economic Studies, vol.48, p.289-309.

Erce, A. (2013), Sovereign Debt Restructurings and the IMF: Implications for Future Official Interventions, Federal Reserve Bank of Dallas Globalization and Monetary Policy Institute Working Paper No. 143, http://www.dallasfed.org/assets/documents/institute/wpapers/2013/0143.pdf

European Commission (2011), Feasibility of Introducing Stability Bonds, Green Paper 23.

European Commission (2014), Assessing Public Debt Sustainability in EU Member States: A Guide, European Economy Occasional Papers 200, September 2014.

European Commission (2014), Expert Group on Debt Redemption Fund and Eurobills: Final Report submitted on 31 March 2014, European Commission, available at http://ec.europa.eu/economy finance/articles/governance/pdf/20140331 conclusion en.pdf.

Eusepi, S. and B. Preston (2012), Debt, Policy Uncertainty and Expectations Stabilization, Journal of the European Economic Association, vol.10(4), p.860-886.

Hamilton, J. and M. Flavin (1986), On the Limitations of Government Borrowing A Framework for Empirical Testing, American Economic Review, vol.76(September), p.809-819.

Herndon, T., M. Ash, and R. Pollin (2014), Does High Public Debt Consistently Stifle Economic Growth? A Critique of Reinhart and Rogoff, Cambridge Journal of Economics, vol. 38(2), p.257-279.

IMF (2003), Sustainability Assessments - Review of Application and Methodological Refinements. Discussion Paper, International Monetary Fund, Washington, DC.

IMF (2009), Fiscal Rules-Anchoring Expectations for Sustainable Public Finances, IMF Fiscal Affairs Department.

Pitchford, R. and M. Wright (2012), Holdouts in Sovereign Debt Restructuring: A Theory of Negotiation in a Weak Contractual Environment, Review of Economic Studies, vol.79, p. 812-837.

Reinhart, C. and K. Rogoff (2010), Growth in a Time of Debt, American Economic Review, vol.100(2), p.573-578. 
Skintzi, V. and A. Refenes (2006), Volatility spillovers and dynamic correlation in European bond markets, Journal of International Money and Finance, vol.16, p.23-40.

Steinbach, A. (2015), The Mutualization of Sovereign Debt: Comparing the American Past and the European Present, Journal of Common Market Studies, forthcoming.

Taylor, J. and J. Williams (2010), Simple and Robust Rules for Monetary Policy, Chapter 15 in the Handbook of Monetary Economics, vol. 3, p.829-859.

Trebesch, C.(2009), The Cost of Aggressive Sovereign Debt Policies: How Much is the Private Sector Affected? IMF Working Paper 09/29.

Zettelmeyer J., C. Trebesch and M. Gulati (2012), The Greek Debt Restructuring: An Autopsy, Economic Policy, vol.28, p.513-563.

\section{$5 \quad$ Appendix}

In case $\alpha_{i}$ equals 0 , our model (1)-(8) is reduced to a special case, where in the absence of any risk premium, governments can borrow at the risk free (corrected for growth) interest rate. In that case, the FD and EB regimes coincide and the dynamics of government debt, deficits and money growth become linear as the risk premium was the cause of the non-linearity in the dynamics:

$$
\left[\begin{array}{c}
\dot{d}_{1}(t) \\
\dot{d}_{2}(t)
\end{array}\right]=\left[\begin{array}{cc}
\bar{r}_{1}-\gamma_{1}-\theta \gamma_{E} & -\theta \gamma_{E} \frac{1-\omega}{\omega} \\
-(1-\theta) \gamma_{E} \frac{\omega}{1-\omega} & \bar{r}_{2}-\gamma_{2}-(1-\theta) \gamma_{E}
\end{array}\right]\left[\begin{array}{c}
d_{1}(t) \\
d_{2}(t)
\end{array}\right]+\left[\begin{array}{c}
\bar{f}_{1}+\gamma_{1} \bar{d}_{1}-\frac{\theta}{\omega} \bar{m}_{E}+\frac{\theta}{\omega} \gamma_{E} \bar{d}_{E}+\overline{s f a}_{1} \\
\bar{f}_{2}+\gamma_{2} \bar{d}_{2}-\frac{1-\theta}{1-\omega} \bar{m}_{E}+\frac{1-\theta}{1-\omega} \gamma_{E} \bar{d}_{E}+\overline{s f a}_{2}
\end{array}\right.
$$

From the linear system (12) a number of properties can be readily determined. Define thereto:

$$
x=\left[\begin{array}{l}
d_{1}(t) \\
d_{2}(t)
\end{array}\right], A=\left[\begin{array}{cc}
\bar{r}_{1}-\gamma_{1}-\theta \gamma_{E} & -\theta \gamma_{E} \frac{1-\omega}{\omega} \\
-(1-\theta) \gamma_{E} \frac{\omega}{1-\omega} & \bar{r}_{2}-\gamma_{2}-(1-\theta) \gamma_{E}
\end{array}\right], \bar{b}=\left[\begin{array}{c}
\bar{f}_{1}+\gamma_{1} \bar{d}_{1}-\frac{\theta}{\omega} \bar{m}_{E}+\frac{\theta}{\omega} \gamma_{E} \bar{d}_{E}+\overline{s f a}_{1} \\
\bar{f}_{2}+\gamma_{2} \bar{d}_{2}-\frac{1-\theta}{1-\omega} \bar{m}_{E}+\frac{1-\theta}{1-\omega} \gamma_{E} \bar{d}_{E}+\overline{s f a}_{2}
\end{array}\right.
$$

so that (12) can be written in the standard form $\dot{x}(t)=A x(t)+b$ for which the following properties hold:

(1) General solution: $x(t)=e^{A t} x(0)$.

(2) Stability: the dynamics of (12) are stable in case all eigenvalues of A have real parts that are smaller than 0 ; the stability conditions $\operatorname{Trace}(A)=\bar{r}_{1}+\bar{r}_{2}-\gamma_{1}-\gamma_{2}-\gamma_{E}<0$ and $\operatorname{Det}(A)=$ $\left(\bar{r}_{1}-\gamma_{1}-\theta \gamma_{E}\right)\left(\bar{r}_{2}-\gamma_{2}-(1-\theta) \gamma_{E}\right)-\theta \gamma_{E} \frac{(1-\omega)}{\omega}(1-\theta) \gamma_{E} \frac{\omega}{(1-\omega)}>0$ are satisfied in that case. The product of the eigenvalues of $\mathrm{A}$ equals its determinant, the sum of the eigenvalues equals the Trace. The eigenvalues of $\mathrm{A}$ are $\lambda_{1}=\frac{1}{2}\left[\operatorname{Trace}(A)+\sqrt{\left(\operatorname{trace}^{2}\right)-4(\text { Det })}\right], \lambda_{2}=\frac{1}{2}\left[\operatorname{Trace}(A)-\sqrt{\left(\text { trace }^{2}\right)-4(\text { Det })}\right]$. In can be easily verified that in for our baseline set of parameters these conditions holds when assuming $\alpha_{i}=0$.

(3) The steady-state of (12) equals: $\bar{x}=-A^{-1} \bar{b}$.

It is interesting to compare the linear model with the non-linear models in the main text of our analysis. Therefore Figure A.1 gives adjustment in case the baseline parameters of Section 3.1 are used in the linear model (where therefore $\alpha_{i}$ equals 0 ): all differences can then be contributed to the non-linearities resulting from risk-premia. 

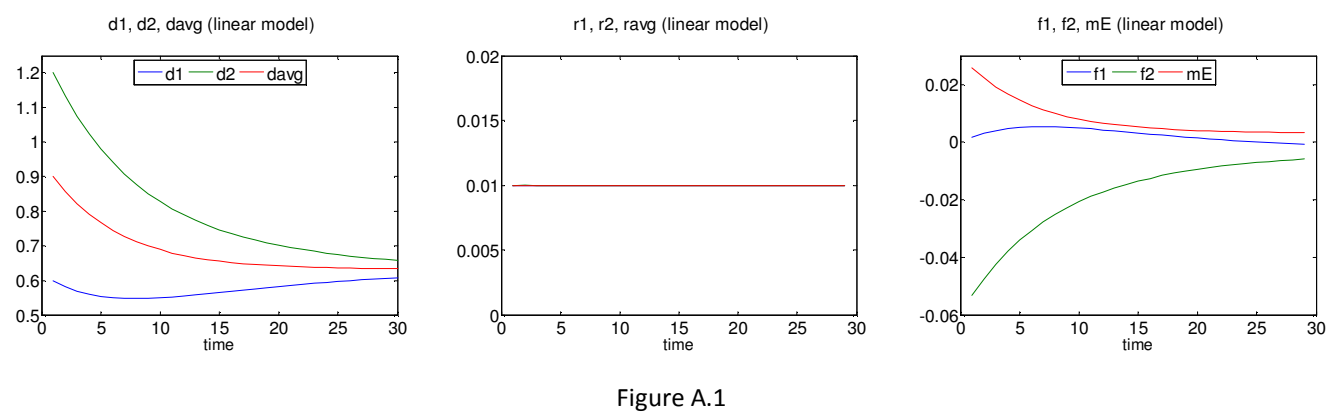

Linear model: baseline

Compared to the baseline of the non-linear models displayed in Figure 1, the linear model has more stable debt dynamics. Government debt and money growth are lower in the absence of risk premia both when compared to the FD and EB cases. The effects on fiscal deficits varies between countries and over time: the average fiscal deficit is larger in the linear model as there is simply less pressure from debt stabilization. In contrast to the non-linear models, debt dynamics in the linear model converge to a unique steady-state whose values are found in Table A.1 together the resulting steady-state values of the primary deficit, money growth and welfare losses.

\begin{tabular}{|c|c|c|c|c|c|c|c|c|c|}
\hline & & $d_{1}(\infty)$ & $f_{1}(\infty)$ & $d_{2}(\infty)$ & $f_{2}(\infty)$ & $m_{E}(\infty$ & $L_{F 1}$ & $L_{F 2}$ & $L_{E}$ \\
\hline Case 1 & baseline & 0.632 & -0.003 & 0.632 & -0.003 & 0.003 & 0.34 & 7.30 & 1.68 \\
\hline Case 2 & $\bar{f}_{2}=0.013$ & 0.602 & -0.000 & 0.714 & -0.001 & 0.006 & 0.21 & 12.89 & 2.68 \\
\hline Case 3 & $s f a_{2}=-0.2$ & 0.632 & -0.003 & 0.632 & -0.003 & 0.003 & 0.27 & 4.28 & \\
\hline Case 4 & $\gamma_{E}=0.15$ & 0.625 & -0.002 & 0.625 & -0.002 & 0.004 & 0.40 & 6.46 & .50 \\
\hline Case 5 & $s f a_{2}=-s f a_{1}=-0.2$ & 0.632 & -0.003 & 0.632 & -0.003 & 0.003 & 0.62 & 3.75 & 6 \\
\hline
\end{tabular}

Table A.1 Steady-state linear debt dynamics case. 
Compared this linear model to the non-linear models, country 2 would gain most from removing risk premia in bond markets. This is intuitive since it starts with high initial debt and high risk premia. Country 1 and the ECB also have lower losses in the linear regime but the differences are smaller. 